\title{
BARON DE WENZEL, OCULIST TO KING GEORGE III: HIS IMPACT ON BRITISH OPHTHALMOLOGISTS
}

\author{
by
}

\author{
A. L. WYMAN *
}

For many centuries, the treatment of eye disease was largely neglected by respectable medical men, and patients resorted to irregular practitioners usually regarded as quacks and charlatans. Even royalty had a predilection for such people, if we go by the examples of Sir William Read, oculist to Queen Anne, and Chevalier Taylor, oculist to George II and George III. The situation began to change about the middle of the eighteenth century, when Jacques Daviel ${ }^{1}$ around 1750, advocated a new treatment for cataract, by extraction instead of the traditional method of couching. The ensuing controversy aroused the interest of surgeons in several countries, and efforts were made to persuade regular surgeons to undertake this work. Yet as late as 1805, when John Cunningham Saunders founded Moorfields Hospital in London, for the cure of eye patients exclusively, it was considered a bold step to specialize in a field so overrun with quacks, and so risk being tarred with the same brush. ${ }^{2}$

In this transitional period, the Baron Michael Johann Baptist de Wenzel (1724-90) succeeded Chevalier (John) Taylor in 1772 as Oculist to the King. ${ }^{3}$ His origins are obscure, but his title of Freiherr or Baron seems to have been genuine, and he probably came from the lower ranks of the gentry. He is often considered to be of German nationality, but the place of his birth is unknown. He early made his way to Paris, and his son became a French citizen. In complete contrast to his predecessor, the Chevalier, who in 1761 claimed to have published 45 works, Wenzel wrote nothing. Much of what we know of him comes from the pen of his devoted son and disciple, Jakob, who, unfortunately, gives us very few personal details. We are told of the extent of the Baron's travels, and of some of the important people he treated, but the information is not always reliable. So strongly was the young Wenzel attached to

*A. L. Wyman, M.D., F.R.C.P., 65 Nassau Road, London SW13 9QG.

I would like to thank my wife Renate, for considerable help in translations, and Mrs. M. P. G. Draper, Archivist of the Bedford Estates, and Dr W. P. Liesching for special references. Consultation of and quotation from the manuscripts cited in notes 10-12, with permission of the Marquess of Tavistock and the Trustees of the Bedford Estates.

${ }^{1}$ Nouvelle biographie générale, Paris, Firmin Didot Frères, 1855, vol. 13, pp. 242-3.

2 E. Treacher Collins, The history and traditions of the Moorfields Eye Hospital, London, H. K. Lewis, 1929, pp. $9-11$.

${ }^{3}$ The official record is missing. There is a gap in the Appointments Book, Series II, PRO.LC3/67, from 1761 to 1773 . 
his father, and so concerned was he to defend his father's achievements that his own personality becomes quite submerged in that of his parent. His books have the authorship ascribed to "de Wenzel (Michel-Jean-Baptiste) fils". It is not surprising that the Larousse of 1876 confuses the two and, under the name of the father, records the career of the son.

A clue to the Baron's background may be provided by an $A k t$ of 1774, in the Austrian archives in Vienna, in which he is described as "Gutsbesitzer in Lothringen"-landowner in Lorraine-and "Wohlgeboren". This may explain the Franco-German associations of the Wenzels, coming from border territory. ${ }^{4} \mathrm{~A}$ print of the Baron in 1789 (plate 1) displays a coat of arms which is reproduced in a standard work by Rietstap, ${ }^{5}$ but it cannot be traced back further and may have been a recent invention.

Cataract extraction, when first introduced, was regarded by many of Daviel's contemporaries as a passing fashion, but Wenzel adopted the new procedure with enthusiasm, and in the course of time improved it. In the Traite de la cataracte of 1786 , the young Wenzel explained that he was describing the methods used by his father for about 35 years. This would be from 1751. He ended with the hope that his book would prove useful as it was the fruit of 40 years' work. ${ }^{6}$ The time may refer to the beginning of the father's career, as the son acknowledged that Daviel introduced the new operation, and the rather ambiguous phraseology is not a claim to priority. In his other book, Manuel de l'oculiste of 1808 , the son claimed that his father, who had died in 1790, enjoyed a great reputation throughout Europe for over 45 years, during which he had extended the frontiers of the art. ${ }^{7}$ This takes us back to 1745 , when he was aged 21 .

There is nothing recorded of Wenzel's work in the 1750s, but by the end of the decade he had made a name for himself. In 1760, he was summoned to Vienna to advise the Empress Maria Theresa about a relaxed eyelid which was soon cured. While there, he successfully operated on Général-Maréchal Molck for cataract, although the distinguished physicians Gerhard Van Swieten and Anton De Haen had diagnosed gutta serena. In the same year, he went to Pest, in Hungary, to operate on the wife of the President of the Council. ${ }^{8}$ By this time, Wenzel was operating all over Europe, and the patients mentioned were usually the rich and the famous.

A good illustration of the reasons for his success, and the rewards that came with it, is given by his treatment of the 4th Duke of Bedford. According to the younger Wenzel, it was in 1765 that the Baron was sent for, ${ }^{9}$ but the actual date was 1767 . The Duke's sight had been failing for some time, and in the end he was unable to write his own letters, as both eyes were affected. In October 1767, his surgeon, Dr Elliott, was

\footnotetext{
${ }^{4}$ Karl Friedrich von Frank, Standeserhebungen und Gnadenakte für das Deutsche Reich und die Österreichischen Erblande bis 1806, Schloss Senftenegg, Selbstverlag, 1974, vol. 5, p. 204.

${ }^{5}$ J. B. Rietstap, General illustrated armoria, ed. V. and H. Rolland, Lyon, Sauvegarde Historique, 1924, vol. 6, plate clix.

${ }^{6} \mathrm{M}$. De Wenzel, fils, Traité de la cataracte, Paris, 1786, pp. viii, xii.

${ }^{7}$ M. De Wenzel, Manuel de l'oculiste, Paris, Lavater, 1808, Preface.

${ }^{8} \mathrm{M}$. De Wenzel Jun., A treatise on the cataract, translated from the French with many additional Remarks by James Ware, London, C. Dilly, 1791, pp. 54, 178.

9 Ibid., p. 184.
} 


\title{
A. L. Wyman
}

of the opinion that the cataracts were not yet mature and that couching was impracticable for the time being. When the cataracts were quite formed, the Duke could "be safely couch'd, and in all probability he will have sight, but that cannot be ascertained for certain". 10 In contrast to this cautious approach, the Baron advised immediate extraction, the sooner the better, and gave him "certain hopes of an Immediate Cure". Writing to Dr Elliott on the day of the operation, 5 December, the Duke's secretary informed him that Baron Wenzel,

\begin{abstract}
this morning performed the Operation and extracted the cataract from each Eye, with very great Expedition and very little pain to His Grace, in the presence of several of the most Eminent Surgeons and others of the Faculty, who expressed the highest Satisfaction at the performance. The Cataracts do each resemble a small Pea flatted [sic] \& of the Colour of Bees Wax.-His Grace Spirits before \& during the operation were extremely good \& have continued so ever since, he remains perfectly quiet with a Bandage over his Eyes and is as well as it is possible. ${ }^{11}$
\end{abstract}

The operation was adjudged a success, and early in 1768, the Baron received his fee of $£ 500$ and his assistant $£ 50 .{ }^{12}$ It was alleged that the Duke also showed his gratitude by supporting Wenzel's application for the post of Oculist to the King, in opposition to the Chevalier's son, John Taylor, when the vacancy occurred in $\mathbf{1 7 7 2}$. However, the Duke had died in 1771, and his successor, the 5th Duke, was his grandson, a child of 5 years. Further, the old Duke had been on bad terms with the King, and his recommendations were unlikely to be welcomed. Wenzel was already Oculist to the Queen of Hungary (Maria Theresa) and was well known throughout Europe, good arguments in his favour. The hostility of the Taylor family was carried on by the Chevalier's grandson, John, who was an oculist as well as a journalist. In 1832, he stated that Wenzel had been a pupil of his grandfather, and he recounted a story that, when the Chevalier met Wenzel on some social occasion, he told him that he had not detected such promise of future fame when he had been his pupil. The Baron, piqued by such remarks, pointed to his shoes, which were decorated with brilliant diamonds, and in a voice loud enough to attract the rest of the Company, said simply "Regardez mes boucles". For once the Chevalier had nothing to say. ${ }^{13}$

In the earlier part of his career, Wenzel's activities centred on Paris. In 1776, he had an address in the rue Chapon au Marais, ${ }^{14}$ but from the following year, he had a house in the rue Charlot, where his son continued to practise well into the next century. ${ }^{15} \mathrm{He}$ also established himself in London, from 1774 in the fashionable and aristocratic Pall Mall, and from 1780 at 6 Sackville Street, on the north side of Piccadilly, ${ }^{16}$ a street which "attracted throughout the eighteenth century the minor nobility, the dowager, the member of Parliament, the senior army officer and the

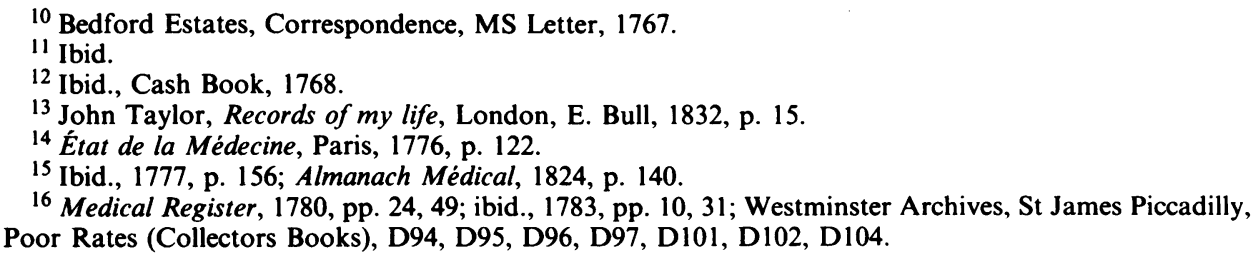




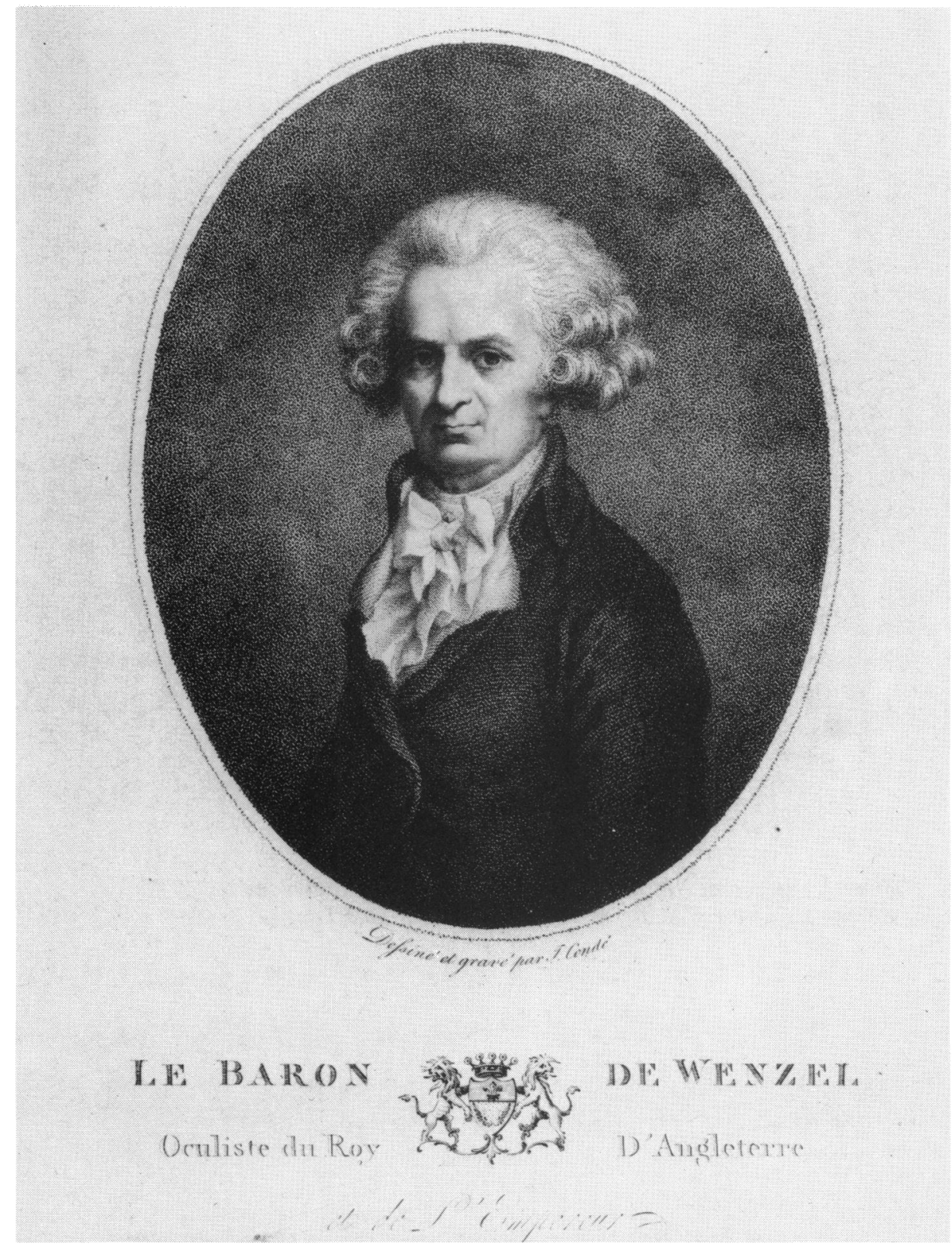

Plate 1. Portrait of Baron de Wenzel. Stipple engraving by J. Condé after himself. (Wellcome Institute Library, London) 


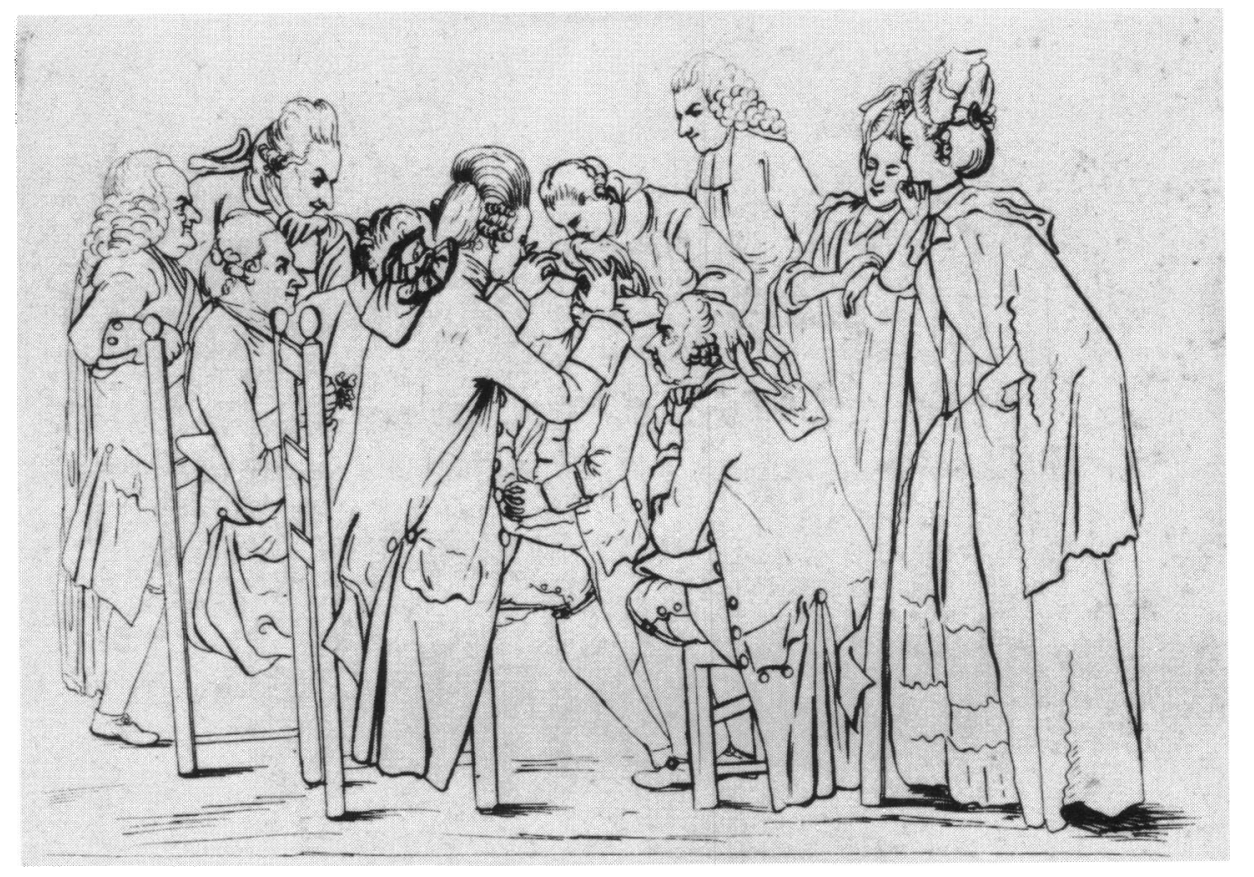

Plate 2. Baron de Wenzel performing an eye operation in Berlin, 1772. Etching by Daniel Chodowiecki. (Wellcome Institute Library, London) 


\section{Baron de Wenzel, Oculist to King George III}

prosperous medical man". ${ }^{17} \mathrm{He}$ died in London on 4 October 1790, at the age of 66 , and was buried four days later in the grounds of the old St Pancras Church. ${ }^{18} \mathrm{His}$ tombstone was inscribed:

$\quad$ Hic jacet
Michael Joannes Baptista de Wenzel
Sancti Imperii Liber Baro
Magnae Britanniae Regis
necnon Reginae Hungariae
celeberrimus Ophthalmiator
E terrestri in aeternam transivit vitam
quarto die Octobris 1790
aetatis suae $66^{19}$

During a nineteenth-century "improvement" of the churchyard, the tombstone was moved and has now disappeared. In spite of his fame, the obituaries in the periodicals were minimal. The deaths column of The Times, for example, merely said, "Sunday, Baron de Wenzel, Oculist to his Britannic Majesty".20 Other magazines offered nothing more; some gave the date as 3 October instead of the 4 th. $^{21}$

During his lifetime, Wenzel enjoyed a very mixed reputation. He was condemned for his greed, his extravagant claims, his lack of education and for the general fault of the itinerant, of disappearing before the results of treatment became manifest. In Regensburg, in 1761, Wenzel, already Oculist to the Imperial Court, was asked by a local surgeon named Schäffer to see one of his patients, a burgher's wife. The fee demanded was 400 Louis d'or, but eventually it was beaten down to 50 ducats. The operation took place on 23 May and was straightforward. The Baron left town on 1 June. In a sour comment, Schäffer hoped that local German surgeons would perform these operations more conscientiously and with more humanity than foreign itinerant pseudo-surgeons, with their eyes only on the money, and whose sole concern, before running off, was what their patient could afford to pay. ${ }^{22}$

Another accusation levelled against the Baron was that he withheld vital details from those he was supposed to instruct. When he was summoned to Vienna in the early 1770 s to operate on some cases, because there was nobody there capable of doing so, the Empress asked him to teach two local surgeons, but on their own they were disastrous. Wenzel was suspected of misleading them, but it is equally possible that it was their inexperience and ineptness which led to bad results. Three years later, Wenzel returned to Vienna and instructed Joseph Barth with more success. Barth, a Maltese, was the first holder of the chair of Ophthalmology in Vienna (1773), indeed

\footnotetext{
17 Survey of London, vol. 32, London, Athlone Press, 1963, p. 352.

18 Gentleman's Magazine, 1791, 61(1): 182; Greater London Record Office, Burials St Pancras Old Church, P90/PAN1.

${ }^{19}$ F. T. Consick, A collection of curious and interesting epitaphs of Saint Pancras, Middlesex, 1869.

20 The Times, 11 Oct. 1790.

${ }^{21}$ European Magazine, 1790, p. 320; The Scots Magazine, 1790, 52: 517; The Gentleman's Magazine, 1790, 60(2): 958

22 Julius Hirschberg, Geschichte der Augenheilkunde, vol. 2, Hildesheim and New York, Georg Olms, 1977, p. 314.
} 


\section{A. L. Wyman}

in the world. Wenzel was very well rewarded for his services. In his first visit, he received 10,000 Gulden for each case, on top of which the Empress presented him with a ring worth 6,000 Gulden. After a stay of nine months, he departed with the vast sum of 75,000 Gulden. ${ }^{23}$

The Baron, aware of his own limitations, left his son in Vienna to study anatomy and diseases of the eye under Barth's tuition, and so become properly trained. The young Wenzel obtained his doctorate in Paris in 1779. By 1783, he was one of the doctors Regent in the Faculty of Physic in Paris, ${ }^{24}$ and by 1786 he was a member of the Faculty of Medicine of Nancy. He later became a member of the Académie de Médecine. ${ }^{25}$ The son thus became part of the medical establishment, and achieved the respectability and recognition denied to the father. Joseph Beer, who later became Professor of Ophthalmology at Vienna, when discussing the Wenzels in 1799, asserted that while the son had full right to the title of "Oculist", the father did not. ${ }^{26}$

Modern writers have also been divided in their opinions. Coats (1933) refers to the "notorious" Baron Wenzel, who, if a pupil of Chevalier Taylor, "evidently learned from him more than the mere dry bones of ophthalmic science". 27 Burton Chance (1962) describes Wenzel as an "ignorant quack who by practising on the blind obtained great skill as a coucher of cataract." 28 Gorin (1982) says merely that the Wenzels were oculists who were looked upon with disapproval by the profession, ${ }^{29}$ but Münchow (1984) recognizes him as the best operator on cataract in Europe after Daviel's death. ${ }^{30}$ Whatever the criticisms of the Baron, it was generally acknowledged that his operative skill was unsurpassed. Dr Andreas Meyer, who saw him in Berlin, found him skilful and quick-too quick! On one occasion, he introduced the knife wrongly, cut upward, and the eye was lost. But such disasters must have been rare. ${ }^{31}$ When Richter objected to some of the Baron's procedures, he hastened to add that perhaps he went too far when he threw even the slightest blame "on Baron Wenzel, that celebrated and that acknowledged very dexterous operator". 32 The English surgeon, James Ware, admired Wenzel's “extraordinary skill in performing the operation". 33 The Wenzel operation was the standard procedure for many years. In 1803 , in a comparison of the treatment by extraction with that of couching, Dr Lacournière, of the medical school of Strasbourg, commented: "Le procédé de Wenzel, étant généralement regardé comme celui qui réunit le plus d'advantages, ayant été d'ailleurs couronné par des succès nombreux, est aujourd'hui le plus

\footnotetext{
23 Ibid., p. 488.

24 Medical Register (1783), op. cit., note 16 above, p. 189.

${ }^{25}$ Maurice Genty (ed.), Index biographique des Membres, des Associés et des Correspondents de l'Académie de Médecine de 1820-1970, Paris, Doin, 1972, p. 193.

${ }^{26}$ G. Joseph Beer, Repertorium, Vienna, Carl Schaumburg, 1799, pt. 3, p. 193.

${ }^{27}$ George Coats, 'The Chevalier Taylor' in R. Rutson James (ed.), Studies in the history of ophthalmology in England prior to the year 1800, Cambridge University Press, 1933, p. 138.

${ }_{28}$ Burton Chance, Ophthalmology, New York, Hafner, 1962, p. 58.

29 George Gorin, History of ophthalmology, Wilmington, Del., Publish or Perish Inc., 1982, p. 64.

30 Wolfgang Münchow, Geschichte der Augenheilkunde, Stuttgart, Ferdinand Enke, 1984, p. 341.

${ }^{31}$ Hirschberg, op. cit., note 22 above, p. 314.

32 A. G. Richter, A treatise on the extraction of the cataract, translated from the German, London, J. Murray, 1791, p. 72.

${ }^{33}$ Wenzel, op. cit., note 8 above, p. i.
} 


\section{Baron de Wenzel, Oculist to King George III}

généralement adopté ..."34 He preferred extraction. In 1815 , in a similar study, the Wenzel procedure was again chosen for the purpose of comparison, although in this case the author preferred couching. ${ }^{35}$

The operation is clearly described and illustrated in the book written by the son. The patient sat in a chair, with an assistant holding the head and raising the upper lid. The Baron, on a higher chair, sat opposite, and steadied the eye with his fingers, not using a speculum or fixation forceps. There was no anaesthetic and the pupil was not dilated. When the eye was still, the knife was "plunged" into the upper and outer part of the cornea, close to the junction with the sclera, obliquely into the anterior chamber, parallel to the plane of the iris. At the pupil, the knife was dipped to puncture the capsule of the lens. It was then withdrawn, and passing through the anterior chamber it was brought out at the inferior margin of the cornea inclined to the inner angle. A crescentic incision was made in the cornea, care being taken not to lacerate the iris. The knife was carefully withdrawn, and by pressure on the globe the lens was dislocated and extruded through the pupillary space. A needle might be used to help in its removal. The operation was usually completed in half a minute. Sometimes there occurred a prolapse of the iris, termed a "staphyloma". Afterwards the patient was put to bed and a dry dressing was applied. It was removed every day to wipe away the tears, but the eyelids were kept closed for 9-10 days. Wenzel was quite enlightened in his approach. He declared that bleeding and purging were unnecessary beforehand, but he advised cutting down the intake of food. In cases of necessity, any season of the year was suitable. ${ }^{36}$

The artist Daniel Chodowiecki saw Wenzel at work in the orphanage of the French colony in Berlin in 1772, and sketched the scene on the spot, although he embellished it prior to publication. Wenzel sits confronting the patient, as described in the Traité, and appears much younger than his 48 years. He is elegantly dressed, wearing a fashionable wig, looking something of a dandy. There are several interested onlookers, although the two young ladies may have been added for artistic purposes (plate 2) ${ }^{37}$ By contrast, the print of the Baron in 1789 by J. Condé (plate 1) depicts him as old and worn and without the buoyancy of youth.

That extraction was a better treatment for cataract than couching was not universally accepted. Although the new operation was quickly taken up by some French surgeons, Daviel himself was at first undecided whether it was an improvement. Extraction was favoured by some English surgeons, such as Samuel Sharp of Guys, Joseph Warner, and Jonathan Wathen; and the German surgeons Augustus Gottlieb Richter and Joseph Beer. On the other hand, such eminent surgeons as Perceval Pott, Guillaume Dupuytren, and Antonio Scarpa preferred couching or depression. The advantages of extraction were not immediately obvious. The translator of Richter's Treatise in 1791 observed that, "were any candid person

\footnotetext{
${ }^{34}$ Lacournière, Considérations sur l'opération de la cataracte; et parallèle entre le procédé de Scarpa et celui de Wenzel, Collection Générale des Dissertations de l'École Speciale de Médecine de Strasbourg, 1803 , vol. 5 , pt. 3, p. 27.

35 Joseph Bonnaric, Dissertation sur les deux méthodes opératoires employées pour la cure de la cataracte, et parallèle entre le procédé de Scarpa et celui de M. le Baron Wenzel, Montpellier, 1815, p. 23.

${ }^{36}$ Wenzel, op. cit., note 8 above, pp. 65-7, 148-54, 223, 237.

${ }^{37}$ Hirschberg, op. cit., note 26 above, pp. 313-14.
} 


\section{A. L. Wyman}

to take the trouble of comparing the operation for Extraction, as proposed by $\mathrm{Mr}$. Daviel, with the operation of Couching as then performed, he will not hesitate in pronouncing in favour of the latter. Since that period however, this new mode of operating has undergone very great improvements ...". ${ }^{38}$ The argument continued well into the nineteenth century. In 1835, Richard Middlemore, surgeon to the Birmingham Eye Infirmary, commented that "Wenzel and Sir William Adams have given us a very gloomy and overcharged account of the evils resulting from depression which Scarpa and Samuel Cooper have very keenly ridiculed and ably refuted." 39

Richter's translator went on: "Hitherto this operation has in England as in Germany, been chiefly confined to the hands of Itinerants, who to do most of them justice, certainly acquire a dexterity which is but seldom to be met with among regular-bred surgeons." ${ }^{40}$ Richter, in his book, originally published in 1770 , tried to persuade "regular-bred" surgeons to take up the new treatment, and his strictures on the itinerants were valid. The actual operation was only half the surgeon's duty: the preparation of the patient beforehand, and careful management afterwards were equally important. Richter was particularly critical of the post-operative care: "These men not only altogether abandon their patients, but at the same time deprive them of the aid they might perhaps receive from a regular bred surgeon ...".41 Wenzel's follow-up of his patients tended to be on the short side, and he sometimes drew conclusions which were not justified. The young Wenzel was keen to record successes, and failures were minimized. He reported, for example, that when his father was in St Petersburg in 1771, he restored the sight of the famous Swiss mathematician Leonhard Euler, who had been going blind for five years. ${ }^{42} \mathrm{He}$ does not tell us that the improvement was only temporary: Euler relapsed into blindness and was dependent on his sons and pupils until his death in $1783 .{ }^{43}$

Despite the charge that Wenzel was secretive about his methods, on the whole he practised his art with great openness. Surgeons interested in eye diseases were often present at his operations, and such expert witnesses would not be easily deceived. In Amsterdam in 1761, Petrus Camper, the great Dutch anatomist and surgeon, watched Wenzel at work. He later remarked that after seeing the success that Wenzel had enjoyed, both locally and all over Europe, there remained no doubt that extraction of the cataract appeared preferable to depression. Camper was one of the first to perform the new operation in The Netherlands. ${ }^{44}$

In 1768 , when a patient presented a particularly difficult problem, Sharp and Gataker were specifically asked to attend. ${ }^{45}$ Samuel Sharp (1700-78) had been a pupil of William Cheselden and had been on the staff of Guy's Hospital. He had visited Paris in 1749, and was the author of two papers on the new method of extracting the

\footnotetext{
${ }^{38}$ Richter, op. cit., note 36 above, p. i.

39 Richard Middlemore, $A$ treatise on the diseases of the eye, vol. 2, London, Longman, 1835, p. 166.

40 Richter op. cit., note 32 above, p. iii.

41 Ibid., pp. 146-7.

42 Wenzel, op. cit., note 8 above, pp. 188-91.

${ }^{43}$ L. Gustave Du Pasquier, Leonard Euler et ses amis, Paris, J. Hermann, 1927, pp. 81-2.

44 Hirschberg, op. cit., note 22 above, p. 315; C. E. Van Nouhuys, 'The lacrimal surgery of Petrus Camper and his contemporaries', Documenta Ophthalmologica, 1988, 68: 125.

${ }^{45}$ Wenzel, op. cit., note 8 above, p. 146.
} 
lens, published in 1753. Wenzel was therefore being observed by an expert in his own field. Likewise, Thomas Gataker, on the staff of St George's Hospital, was the author of a small book on the anatomy of the eye published in 1761 . He was a keen follower of the Baron, and had been present at the operation on the Duke of Bedford. A contemporary wrote that "Mr. Wathen attended with the late Mr. Gatiker [sic] most of the late Baron de Wenzel's operations for a considerable time after his introduction into this country." ${ }^{46}$ Wathen himself was the author of a dissertation on the subject, in which we find a couple of scanty references to Wenzel. ${ }^{47}$ Another close observer was Wathen's partner, James Ware (1756-1815) who had studied surgery at the Haslar Naval Hospital and at St Thomas's, and had practised chiefly as an ophthalmic surgeon after the partnership was dissolved in 1791. He was a philanthropist, setting up a school for the indigent blind in 1800, and he became a Fellow of the Royal Society in 1804. Ware and Wathen have been praised for elevating "ophthalmic surgery from the degraded condition into which it had fallen. Originally a branch of general surgery but always invaded by quacks, it fell into dishonest hands, from which the disinterested efforts of men like these rescued it."48 The opinion of a man like Ware is therefore very important in forming our judgement of Wenzel. He had not only translated the Traité de la cataracte in 1791, but also thought it worthwhile to produce a new edition over 20 years later in $1812 .{ }^{49}$ Ware tells us that though he had been interested in eye surgery for many years, and had carefully read all the relevant literature, both English and foreign, and had tried out many new suggestions by professional writers, he had derived "the most useful and most important information from the opportunities with which he was favoured of seeing the Baron operate and from remarks occasionally made by the Baron on the different parts of his process." 50

From Ware's remarks and Gataker's actions we can see Wenzel's influence on the eye surgeons of Great Britain. This extended to the next generation, as we may guess from the entry in the notebook of a young Edinburgh medical student referring to Wenzel's visit in $1769 .{ }^{51}$ Further afield, his work became known in New England through the medium of Philip Syng Physick (1768-1837) the "Father of American Surgery" who came to England in 1788, and became the pupil of John Hunter, and later his assistant. After an appointment at St George's Hospital, he went up to Edinburgh, where he graduated in medicine in 1792. Eye surgery was of particular interest to him, and the first case in his private journal is that of a blind woman treated by cataract extraction in the manner of Baron Wenzel, notwithstanding that couching was the order of the day in New England at the time. ${ }^{52} \mathrm{~A}$ set of Wenzel

\footnotetext{
${ }^{46}$ In James (ed.), op. cit., note 27 above, p. 114.

47 Jonathan Wathen, $A$ dissertation on the theory and cure of the cataract, in which the practice of extraction is supported, London, T. Cadell \& C. Dilly, 1785.

48 Dictionary of National Biography.

${ }^{49}$ James Ware, Observations on the cataract, 3rd ed., London, 1812. This contains his translation of De Wenzel's Traité, together with his own comments.

${ }^{50}$ Wenzel, op. cit., note 8 above, pp. i-ii.

${ }^{51}$ D. W. Taylor, 'The manuscript lecture-notes of Alexander Monro, secundus (1733-1817)', Med. Hist., 1978, 22: 174-86.

52 Burton Chance, 'A sketch of the early days of ophthalmology in Philadelphia', Archs Ophthalmol., 1937, 18: $23-45$.
} 


\section{A. L. Wyman}

instruments in the museum of the College of Physicians in Philadelphia may have originally belonged to Physick. Some of them are sketched in the notes of one of his pupils (1808-10). ${ }^{53}$ The other pioneer of extraction in America was the surgeon George Frick, who had been a pupil of Beer in Vienna, but from his book, $A$ treatise on the diseases of the eyes, it is evident that he was acquainted with the views and practice of Wenzel. ${ }^{54}$

With the development of a new operation for a common condition, it was inevitable that pioneer surgeons would invent new instruments and modify the old. Daviel had opened the cornea with a scissors, but it was soon suggested that the cut should be made with a knife. Samuel Sharp was the first to do this and had a special knife made. By 1805, there were 49 different types, including one invented by the Baron. ${ }^{55}$ After Richter demonstrated his own knife at Göttingen around 1770, the young Wenzel claimed indignantly that the idea was stolen from his father, who had used the same knife some 20 years before. He accused Richter of providing himself, while on a visit to London, with a dozen instruments made for Wenzel by the cutler Savigny. ${ }^{56}$ Most commentators are agreed that the two knives are not the same and that there was no plagiarism. Frick, writing in the 1820 s, remarked that though many improvements had been made on the instruments for performing cataract operations "those of Richter and Wenzel alone maintain a place in modern practice". 57 The ghosts of the elder Wenzel and Richter could embrace!

Paul Savigny was the first cutler in England to become a specialist maker of surgical instruments, after he bought the business of a cutler's widow in about 1720 . It was carried on by his son and grandson. In the firm's first catalogue, produced by J. H. Savigny in 1798, there are several illustrations of ophthalmic instruments devised by the leading eye surgeons, and both Wenzel's and Richter's knives are shown. ${ }^{58}$ There was also a Wenzel forceps for removing the lens capsule. The Wenzel knife was in use well into the nineteenth century: Fritze's Miniature Armamentarium of 1836 illustrates Wenzel's "Staarmesser", 59 and when a new method of intracapsular extraction was described in 1845, a Beer or Wenzel knife was recommended. ${ }^{60}$ Johann Alexander Brambilla, an Austrian military surgeon, introduced several new types of forceps, which appeared in England in 1780, and according to one authority, they were undoubtedly of the Baron's invention. ${ }^{61}$

The young Wenzel occasionally mentioned poor patients, and the spirit of philanthropy, real or assumed, that arose in the eighteenth century, also affected the Baron. When he visited Edinburgh in 1769 , he offered to treat the poor gratis if they

53 Idem, 'Baron Wenzel's operation', Am. J. Ophthalmol., 1954, 38: 518-24.

${ }_{54}^{54}$ George Frick, $A$ treatise on the diseases of the eye, London, J. Anderson, 1826, pp. 175, 181, 182.

${ }^{55}$ Gorin, op. cit., note 29 above, p. 48.

${ }^{56}$ Wenzel, op. cit., note 6 above, p. 31.

${ }^{57}$ Frick, op. cit., note 54 above, p. 181.

$58 \mathrm{~J}$. H. Savigny, A collection of engravings representing the most modern and improved instruments used in the practice of surgery with appropriate explanations, London, The Letter-Press, T. Bensley, 1798.

${ }^{59}$ Chance, op. cit., note 53 above, p. 522 , fig. 5.

${ }^{60}$ Casey A. Wood (ed.), The American encyclopedia and dictionary of ophthalmology, vol. 3, Chicago, Cleveland Press, 1921, p. 1510.

${ }^{61}$ E. Bennion, Antique medical instruments, London, University of California Press and Sotheby Parke Bernet, 1979, p. 66. 


\section{Baron de Wenzel, Oculist to King George III}

presented themselves to his lodgings. Gentlemen of the Faculty and other people of distinction were invited to come and watch. ${ }^{62}$ In London, he offered to remove the cataract of a blind boy in the Foundling Hospital free of charge, but the boy could not make up his mind and remained blind. ${ }^{63}$ In 1776, the overseers of the poor of the parish of Fulham gave 7 shillings in relief to a couple, "while under the care of the Baron de Wenzell for their Eyes". ${ }^{64}$ In Paris, the abbé Desmonceaux praised the compassion with which the Baron treated the poor patients that came to see him. ${ }^{65} \mathrm{It}$ could cynically be observed that treating the poor was a way of enlarging his experience and a subtle way of advertising, but the same objections could apply to regular surgeons and physicians who did the same thing.

Although Wenzel was mainly concerned with the treatment of cataract, he also dealt with other eye conditions. In the creation of the artificial pupil, Cheselden was the first to divide the iris but, according to Frick, this was repeated with little success. Wenzel was the first to propose and carry out the practice of cutting out a portion of the iris, a great improvement on previous methods. With a little modification, it was the procedure used in Frick's day. ${ }^{66}$ Another original piece of work that fell to Wenzel was the alleviation of high myopia in young people by the extraction of the lens. He was persuaded to do this by the abbé Desmonceaux sometime before 1775. The abbé, who practised medicine among the poor of Paris, was specially interested in eye diseases, but he was not the first to propose this treatment. Couching or extraction had been suggested by Joseph Higgs of Birmingham in 1745, and by Albrecht von Haller in $1763 .{ }^{67}$ However, nobody had put the idea into practice, and it was Wenzel who was the first to carry out the operation. The results could not have been good, as we hear little more of this development, but the abbé was still strongly in favour of it in his Traité of 1786.68

The scorn of an academic like Beer, and the hostility of other contemporary surgeons towards Wenzel arose from more than personal antipathy. Ophthalmology was one of the first branches of medicine to become a speciality. Specialization was regarded by most eighteenth-century medical men as equivalent to charlatanism. As George Rosen pointed out, "This attitude represents the initial response to the first appearance of modern specialism .... The unfavourable history of earlier forms of specialization provided the basis for this attitude of rejection." 69 There was also a conviction that no one could treat eye diseases successfully unless he practised general surgery. "No one, except the thorough surgeon, can make the complete oculist ...", as Samuel Cooper put it in $1815 .^{70}$ Middlemore took the same attitude 20 years later:

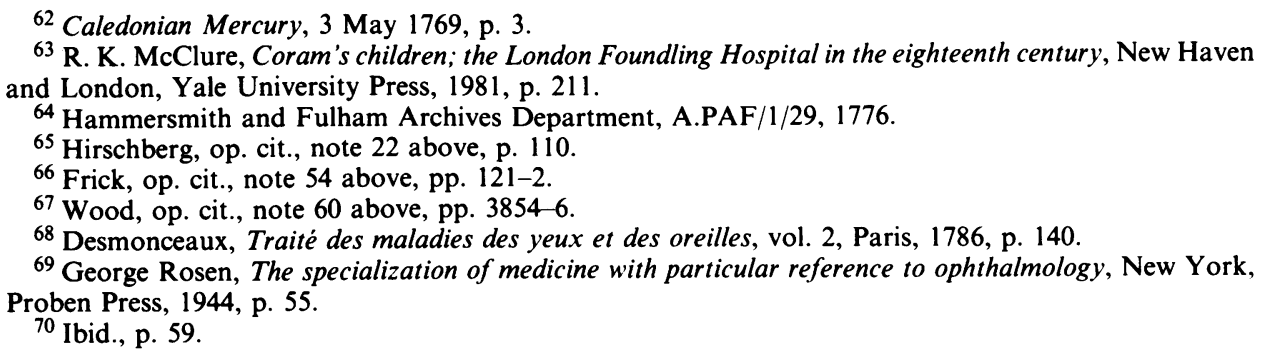




\section{A. L. Wyman}

I am quite willing to admit that some great names of great professional responsibility may be found among the catalogue of those who have, in a great measure, if not altogether, avowedly, limited their practice to the management of ophthalmic maladies; such, for instance, as Wenzel, Ware, Saunders, Adams, Curtis, ec., but I submit that by far the best works on diseases of the eye, and beyond comparison the most useful discoveries and material improvements in this department of knowledge, have emanated from those who studied ophthalmology as a part of, and in connexion with, their profession generally ...

In the second category he included Cheselden, Pott, Warner, Richter, Scarpa, Barth, and others. ${ }^{71}$ The Baron was undoubtedly a specialist, and there is no hint that he was trained in or ever practised general surgery. Such a person would be viewed with deep suspicion by most regular medical men. His success would hardly have helped to endear him to his critics. Hostility was probably aggravated in the late eighteenth century, because the itinerants, who had largely been left to deal with eye troubles, began to be threatened by regular surgeons who wanted to take over this province. Regular surgeons like Richter and Ware were eventually able to persuade their fellows that ophthalmology was a respectable sphere of practice, and the days of the itinerants were numbered. The changing pattern was perceived by Wenzel himself, when he left his son in Vienna to be trained by Barth.

If we try to appraise the career of the Baron de Wenzel, it becomes clear that he was no mere charlatan, as the term is ordinarily understood. His original medical training may have been irregular and scanty, but he mastered his speciality as an oculist. His great skill earned the respect of his peers, and helped to popularize the new treatment of cataract extraction. His work in Vienna, and the impression it made on the Empress Maria Theresa, led to the foundation of a professorial chair and the beginning of a great school of ophthalmology in that city. Far from being secretive, he was a mentor to Professors Barth and Camper, and to British eye surgeons like Ware, Gataker, Wathen and others. His influence spread to the United States when Physick and Frick returned home. The books written by his son, Traité de la cataracte (1786) and Manuel de l'oculiste, ou Dictionnaire ophthalmologique (1808) were based on the views and experience of the father, and were important in their day. The dictionary was the first of its kind in the literature. Nearly 30 years after its publication, Middlemore was still able to commend "the utility of a production which comprises so much requisite information on a very diffuse and extensive subject in so compact and accessible a form."72

It is 200 years since Baron de Wenzel died, and the time is appropriate to reassess his career and clear up the misconceptions about him. Both he and his son made useful contributions to ophthalmology and these could now be acknowledged.

\footnotetext{
${ }^{71}$ Middlemore, op. cit., note 39 above, vol. 1, p. 11.

72 Ibid., p. 17.
} 